\title{
Chemical convergence between a guild of facultative myrmecophilous caterpillars
} and host plants

Chemical convergence in caterpillars

\section{LUAN DIAS LIMA ${ }^{1}$, JOSÉ ROBERTO TRIGO ${ }^{2, \dagger}$, and LUCAS AUGUSTO}

$$
\mathrm{KAMINSKI}^{1, *}
$$

1 Programa de Pós-Graduação em Biologia Animal, Departamento de Zoologia, Universidade Federal do Rio Grande do Sul, CEP 91501-970, Porto Alegre, Rio Grande do Sul, Brazil. ORCiDs: LDL: 0000-0001-5414-3427; LAK: 0000-0002-6468-0960 + +55

(51) 3308-7702 ; *Corresponding author: E-mail: lucaskaminski@ yahoo.com.br

${ }^{2}$ Departamento de Biologia Animal, Instituto de Biologia, Universidade Estadual de Campinas, CEP 13083-970, Campinas, São Paulo, Brazil. ORCiD: 0000-0003-30285353. ${ }^{\dagger}$ Author deceased November $28^{\text {th }} 2017$

\footnotetext{
Abstract. 1. Ants exert a strong selective pressure on herbivorous insects, although some caterpillars can live in symbiosis with them using chemical defensive strategies.

2. We investigated the adaptive resemblance of cuticular hydrocarbons (CHCs) in multitrophic systems involving a guild of facultative myrmecophilous caterpillar species (Lepidoptera: Lycaenidae), tending ants (Hymenoptera: Formicidae) and host plants from three families. We hypothesized that the $\mathrm{CHCs}$ of the caterpillars would resemble those of their host plants (chemical camouflage).
} 
24 3. We analyzed CHCs using gas chromatography/mass spectrometry. Morisita's similarity index (SI) was used to compare CHC profiles of caterpillar species with different types of ant associations (commensal or mutualistic), ants and host plants.

4. We found strong convergence between caterpillars' CHCs and plants, especially for commensal species that do not provide secretion rewards for ants. Moreover, we found unexpected chemical convergence among mutualistic caterpillar species that offer nectar reward secretions to ants.

5. These results show that the studied caterpillars acquire $\mathrm{CHCs}$ through their diet and that they vary according to host plant species and type of ant association (commensalism or mutualism). This 'chemical camouflage' of myrmecophilous caterpillars may have arisen as a defensive strategy allowing coexistence with ants on plants, whereas 'chemical conspicuousness' may have evolved in the context of honest signaling between true mutualistic partners.

6. We suggest the existence of both Müllerian and Batesian chemical mimicry rings among myrmecophilous caterpillar species. Cuticular chemical mixtures can play a key adaptive role in decreasing ant attacks and increasing caterpillar survival in multimodal systems.

42 Key words. Ant-plant-herbivore interactions, chemical camouflage, chemical crypsis, 43 chemical phytomimesis, chemical strategy, symbiosis. 


\section{Graphical abstract}

- Chemical camouflage can be a defensive strategy of myrmecophilous caterpillars against ants.

- 'Chemical conspicuousness' is proposed as a new strategy mediated by cuticular hydrocarbons in myrmecophilous caterpillars.

- Chemical mimicry rings can occur between myrmecophilous caterpillars and especially between mutualistic species that produce nectar rewards for ants.

\section{Myrmecophilous caterpillars from the chemo-sensory perspective of ants}

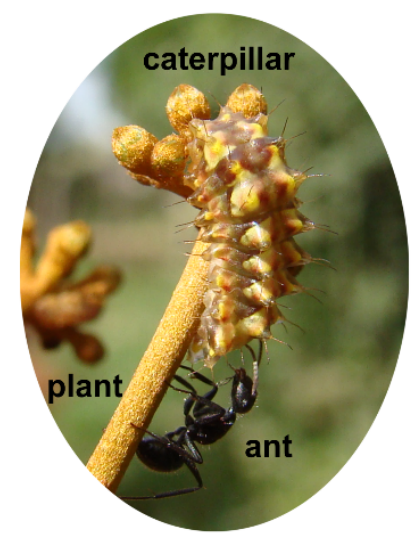

Multitrophic system

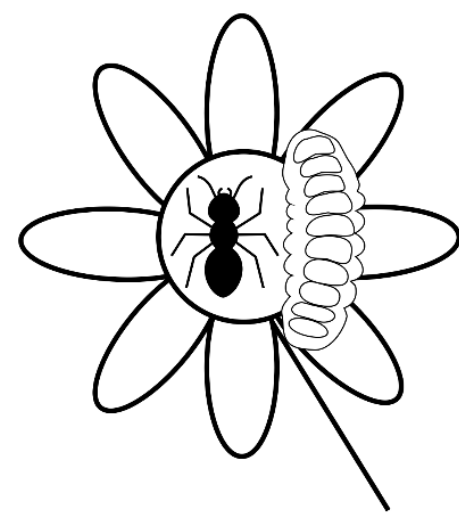

Chemical camouflage

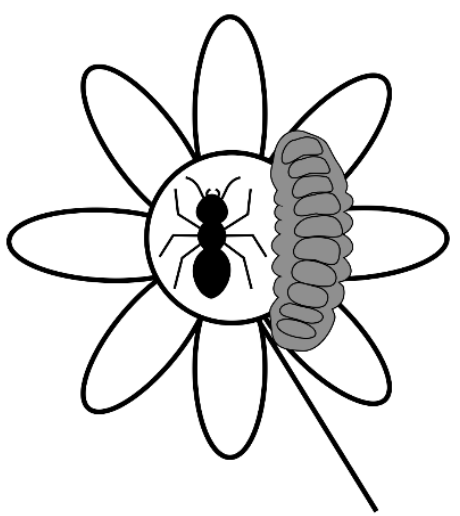

Chemical conspicuousness 


\section{Introduction}

Herbivorous insects suffer a top-down effect from predators and parasitoids (Vidal \& Murphy, 2018). Strategies that minimize detection or attack after detection, as well as deceive these natural enemies, will be positively selected and spread within herbivorous insect species (see Ruxton et al., 2004). Among top predators in terrestrial ecosystems, ants patrolling foliage are considered to apply strong selective pressure on herbivorous insects (Floren et al., 2002). However, some myrmecophilous herbivores, such as hemipterans (e.g. aphids, scales, coccids, whiteflies, leafhoppers, and treehoppers), lepidopteran caterpillars (Lycaenidae and Riodinidae), and aphids and cynipid wasps (via galls), can release liquid rewards rich in sugar (honeydew) that attract tending ants (see Pierce et al., 2002; Pierce, 2019; Pringle, 2020). Such a symbiotic relationship between ants and the trophobiont insects that they attend is termed trophobiosis (Gibernau \& Dejean, 2001). The attraction of tending ants can protect trophobiont herbivores against predators and parasitoids as a conditional mutualism since ants patrolling foliage behave aggressively against any foreign arthropod (see Rico-Gray \& Oliveira, 2007 and references therein for examples with hemipterans).

Trophobiosis is particularly interesting in lycaenid and riodinid caterpillars. These caterpillars do not excrete the excess of sugar-rich phloem as honeydew-producing hemipterans do, but instead produce costly secretion rewards through specialized glands (Daniels et al., 2005; Kaminski \& Rodrigues, 2011). This secretion of lycaenid caterpillars has been reported to manipulate the behavior of tending ants (Hojo et al., 2015). Furthermore, myrmecophilous caterpillars possess behavioral traits and sets of specialized 'ant-organs' used for chemical and acoustic communication with tending ants (Malicky, 1970; DeVries, 1990; Fiedler et al., 1996; Casacci et al., 2019). However, a question remains: Is the nutritional reward offered by trophobiont caterpillars sufficient 
to deter ant aggressive behavior, or have additional defensive mechanisms evolved to avoid predation? Several studies have shown that tending ants may prey upon honeydewproducing aphids (e.g. Sakata et al., 1995; Fischer et al., 2001). Thus, an alternative strategy may be 'chemical camouflage' (sensu von Beeren et al., 2012), by which an operator does not detect an emitter because its chemical cues blend with the environment and, thus, no reaction is caused in the operator. This strategy is found in the myrmecophilous treehopper Guayaquila xiphias (Fabricius) (Hemiptera: Membracidae) due to the high degree of similarity between its cuticular hydrocarbons (CHCs) and its host plant Schefflera vinosa (Cham. \& Schltdl.) Frodin \& Fiaschi (Araliaceae) and seems to solve the dilemma of attracting aggressive tending ants, since these predators fail to recognize the hemipteran as prey (Silveira et al., 2010). Thus, we aimed to investigate the adaptive resemblance among $\mathrm{CHC}$ profiles in three multitrophic systems involving a guild of facultative myrmecophilous caterpillars, tending ants and host plant species (Fig. 1). These caterpillars are polyphagous with color pattern associated with visual camouflage (polychromatism) (see Monteiro, 1991). Thus, we hypothesized that these caterpillars would have $\mathrm{CHC}$ profiles that resemble those of their host plants, suggesting chemical camouflage as an additional defensive mechanism against aggressive ants.

\section{Materials and methods}

\section{Study Site and Organisms}

Collections were carried out in two areas of Cerrado (Brazilian savanna) in the state of São Paulo, in Southeast Brazil: a small fragment belonging to Laboratório Nacional de Luz Síncrotron in the city of Campinas $\left(22^{\circ} 48^{\prime} \mathrm{S}, 47^{\circ} 03^{\prime} \mathrm{W}\right)$; and a reserve of Estação Experimental de Mogi-Guaçu in the city of Mogi Guaçu $\left(22^{\circ} 18^{\prime} \mathrm{S}, 47^{\circ} 10^{\prime} \mathrm{W}\right)$. The vegetation of both sites consists of cerrado sensu stricto, a dense scrubland of shrubs and 
trees (Oliveira-Filho \& Ratter, 2002). The collection and transport of the specimens were authorized by the Sistema de Autorização e Informação em Biodiversidade (SISBIO) by the license No. 62345-1.

Neotropical lycaenid butterflies are included in three subfamilies, within which Eumaeini is the most diverse tribe (Robbins, 2004). Eumaeini caterpillars are generally polyphagous and feed on reproductive tissue (buds and flowers) of host plants (see Robbins \& Aiello, 1982; Kaminski et al., 2012; Silva et al., 2014). These caterpillars are engaged in low-degree facultative interactions with tending ants, although several species seem to have lost myrmecophily (Fiedler, 1991; LAK, unpublished data). Immatures (eggs and caterpillars) of eumaeine species were collected from three host plant species that are commonly used by these caterpillars at the study sites (see Kaminski \& Freitas, 2010; Kaminski et al., 2010b, 2012; Rodrigues et al., 2010): Byrsonima intermedia A. Juss. (Malpighiaceae), Pyrostegia venusta (Ker-Gawl.) Miers (Bignoniaceae) and Schefflera vinosa (Araliaceae). Six eumaeine species were collected from the inflorescences of these plants (Fig. 1): (1) Allosmaitia strophius (Godart) is an oligophagous caterpillar specialized on inflorescences of Malpighiaceae (Kaminski \& Freitas, 2010). Although females prefer to oviposit on plants with ants (Bächtold et al., 2014), the caterpillars have a non-functional dorsal nectary organ (DNO) - that is, they do not establish a typical food-for defense mutualistic interaction with ants, and thus are considered commensal myrmecophilous (i.e. an organism that indirectly interacts with ants) (Kaminski \& Freitas, 2010; Silva et al., 2014). (2) Chalybs hassan (Stoll) is a polyphagous caterpillar on flower buds of Araliaceae, Fabaceae, Sapindaceae, and Sterculiaceae (LAK, unpublished data). They possess a DNO, but there is no evidence regarding its functionality and role in myrmecophily. (3) Michaelus thordesa (Hewitson) is a polyphagous caterpillar, but occurs most frequently on tubular flower buds of 
127 Bignoniaceae, and lives inside of flowers. It is a facultative myrmecophilous with a functional DNO (Silva et al., 2014; Thiele \& Kaminski, in prep.). (4) Parrhasius polibetes (Stoll) is a polyphagous caterpillar that is facultative myrmecophilous with a functional DNO beginning in the third instar, while it is commensal myrmecophilous in the first and second (Kaminski et al., 2010a, 2012; Rodrigues et al., 2010). (5) Rekoa marius (Lucas) is a polyphagous caterpillar that is facultative myrmecophilous with functional DNOs on the third and last instars (Monteiro, 1991; Silva et al., 2014; Faynel et al., 2017). (6) Rekoa stagira (Hewitson) is a polyphagous caterpillar that is facultative myrmecophilous with functional DNOs on the third and last instars (Faynel et al., 2017; LAK, unpublished data). Mayr were collected from the host plants. These species are very common in the Cerrado and are involved in most of the interactions between ants and trophobionts on plants, including myrmecophilous caterpillars (e.g. Alves-Silva et al., 2013; Bächtold, 2014; Lange et al., 2019).

The hatched eggs and caterpillars were reared on buds or flowers of their respective host plant in an uncontrolled environment in the laboratory. For chemical analysis, the desired developmental stage (different larval instars) of the butterflies, the buds or flowers of host plants, and the tending ants were killed by freezing and kept frozen at $-20^{\circ} \mathrm{C}$ until the CHC extraction. When available, both the second instar, which does not produce a 147 reward secretion, and the fourth instar (last instar from now on), which may produce one, were collected. The following samples were collected for analysis: $B$. intermedia $(\mathrm{N}=2$ bud, $\mathrm{N}=1$ flower); $P$. venusta $(\mathrm{N}=1$ bud, $\mathrm{N}=1$ flower $) ; S$. vinosa $(\mathrm{N}=1$ bud $) ; A$. 
152 instar on $B$. intermedia, $\mathrm{N}=4$ last instar on $P$. venusta, and $\mathrm{N}=1$ last instar on $S$. vinosa);

$153 R$. marius $(\mathrm{N}=1$ last instar on $P$. venusta and $\mathrm{N}=1$ last instar on $S$. vinosa $) ; R$. stagira

$154(\mathrm{~N}=1$ last instar on B. intermedia); C. blandus $(\mathrm{N}=1$ pool of 20 workers $)$ and C. crassus

$155(\mathrm{~N}=1$ pool of 20 workers $)$.

Extraction and Identification of Cuticular Compounds

CHCs of the organisms were extracted following Portugal \& Trigo (2005). The

min and then removed with a forceps. The hexane was subsequently treated with

anhydrous $\mathrm{Na}_{2} \mathrm{SO}_{4}$, filtered, and evaporated gently in a stream of $\mathrm{N}_{2}$. The CHC extracts

were analyzed using electron impact gas chromatography-mass spectrometry in a gas chromatograph (Hewlett Packard 6890) equipped with HP-5MS column (5\% phenyl under the following conditions: $250^{\circ} \mathrm{C}$ temperature of injection; $60^{\circ}$ to $300^{\circ} \mathrm{C}$ at $2^{\circ} \mathrm{C} / \mathrm{min}$, $20 \mathrm{~min}$ at $300^{\circ} \mathrm{C}$ program temperature; helium $1 \mathrm{~mL} / \mathrm{min}$ as carrier gas; ionization energy of $70 \mathrm{eV}$ and a range of 40-600 amu; splitless injection mode, $1 \mu \mathrm{l}$ injected. All samples were analyzed with and without co-injection with consecutive $n$-alkane standards for the determination of Kovats Retention Index (KI). Alkanes and alkenes were identified by their KI (Carlson et al., 1998) and fragmentation patterns (Nelson et al., 1981; Pomonis, 1989; Carlson et al., 1999; Howard, 2001). Alkene identification was confirmed after derivatization with dimethyl disulfide for determining the double-bond position (Francis \& Veland, 1981). The fragmentation pattern of $n$-alcohols was compared with those in the literature (Wang et al., 2007). The identification of $n$-alcohols was confirmed after derivatization with $N$-methyl- $N$-trimethylsilytrifluoruoacetamide (MSTFA; $100 \mathrm{~mL}$ 
177 MSTFA, $80^{\circ} \mathrm{C}, 1 \mathrm{~h}$ ) according to Menéndez et al. (2005). Some cuticular compounds

178 were tentatively assigned (e.g. squalene-like) using the NIST Mass Spectral Search

179 Program (Agilent Technologies, Version 2.0 f. 2008) together with mass fragmentation

180 interpretation of Budzikiewicz et al. (1967). The remaining compounds remained as

181 unknowns.

Statistical Analyses

To test our hypothesis, we calculated percentages of absolute abundance of the

data were then used to calculate relative abundances, that is, the quantity of each separate compound expressed as a percentage of the total occurrence of the class of substance. We performed a cluster analysis using Morisita's similarity index (SI) to compare CHC profiles of the studied species. This index varies from $0 \%$ (no similarity) to $100 \%$ (complete similarity) (Krebs, 1999). We used an analysis of similarity (ANOSIM) to test significant differences based on the percentage of similarity of the $\mathrm{CHC}$ profiles between species. Data were partitioned into two separate analysis to facilitate comparisons. First, the species were divided into three groups: caterpillars (group 1), ants (group 2), and plants (group 3). Second, the species were divided into four groups: commensal 4). In these analyses, $R$ values from close or equal to 0 (total similarity) to 1 (total

197 difference) were calculated between the groups (see Clarke, 1993). As C. hassan did not have any kind of ant association (commensal or mutualistic) confirmed, it was not analyzed in the second comparison. All analyses were performed with PAST software (Version 4.03). Values of similarity above $80 \%$ between caterpillars and host plants were considered possible cases of chemical camouflage strategy. This value was defined based 
on the bioassays carried out by Silveira et al. (2010), who showed this value to be sufficient to significantly reduce detection of myrmecophilous insects chemically camouflaged against ants of the genus Camponotus.

\section{Results}

207 Gas chromatography-mass spectrometry analyses of cuticular extracts revealed a high degree of similarity between eumaeine caterpillars and their host plants $\left(\mathrm{R}_{\text {ANOSIM }}=0.20\right.$; $\mathrm{P}<0.05$ ) (Figs. 2-3 and 5; Tables 1 and S1-S5). In general, the caterpillars and their host plants had $n$-alkanes (C27 and C29) as their main components (Figs. 2-3; Tables S1-S3). The highest SI values were between caterpillars that fed on $B$. intermedia, which ranged from $35 \%$ to $98 \%$, followed by those that fed on P. venusta, ranging from $55 \%$ to $90 \%$. Similarity was low for caterpillars on $S$. vinosa, ranging from $23 \%$ to $34 \%$ (Figs. $2-3$ and 5; Table 1). Evidence of chemical camouflage (similarity $>80 \%$ ) was found for four caterpillar species: A. strophius (98\%), P. polibetes (second instar) (96\%) and R. stagira (96\%) on B. intermedia, and R. marius on P. venusta (90\%) (Fig. 5). The highest values of convergence with the host plant were for commensal myrmecophilous that do not have a functional DNO that produces nectar rewards $\left(\mathrm{R}_{\mathrm{ANOSIM}}=-0.08 ; \mathrm{P}>0.05\right)$, namely $A$. strophius (98\%) and the second instar of P. polibetes (96\%) (Figs. 2-3 and 5; Tables 1 and S5).

Last instars of the mutualistic myrmecophilous $P$. polibetes and $R$. marius have conspicuous and less variable profiles that are less affected by host plant composition. Surprisingly, there were also high SI values between some caterpillar species regardless of the host plant. For example, similarities between the last instars of $M$. thordesa and $P$. polibetes (from $84 \%$ to $95 \%$ ) and last instars of C. hassan and M. thordesa (76\%) were higher than the similarities with their host plants (Figs. 2-3; Table 1). In general, the SI 
values for the last instar of $P$. polibetes were higher with other caterpillars (25\% to $95 \%$ )

than of the host plant used (27\% to 66\%) (Figs. 2-3; Table 1). Moreover, the mutualistic

In contrast, the chemical similarity between the caterpillars and ants of the genus

Camponotus was lower and with a different pattern of cuticular compounds (SIs $<23 \%$,

ANOSIM R RNOSIM $=1 ; \mathrm{P}<0.05)$ (Figs. 4-5; Tables 1, S1, and S4-S5). Worker ants of $C$.

blandus and C. crassus had mainly branched alkanes and unidentified compounds, with

\section{Discussion}

We found a high degree of similarity between the CHC profiles (> 80\%) of some species of myrmecophilous caterpillars and of host plants from two of the plant families analyzed caterpillars were congruent with the profiles of the plants they were feeding on suggests that these caterpillars can acquire these profiles through their diet. It has been shown that the diet can be essential on the chemical camouflage strategy (e.g. Akino et al., 2004; Lohman et al., 2006; Lima et al., in prep.). This kind of chemical camouflage, also referred to as chemical crypsis or phytomimesis, was suggested by Espelie et al. (1991) who found similarity between the cuticular lipids of herbivorous insects and their host

247 plants (see Akino et al., 2004; Akino, 2005, 2008; von Beeren et al., 2012; Lima \& Kaminski, 2019). The phenomenon was later reported for the first time for a nontrophobiont, namely the caterpillar of Biston robustum Butler (Geometridae) (Akino et 
the beetle Chelymorpha reimoseri Spaeth (Chrysomelidae) and wasps, also possess this defensive strategy against chemically oriented predators, including ants, for example

254 (Portugal \& Trigo, 2005; Piskorski et al., 2010; Massuda \& Trigo, 2014; Ranganathan et al., 2015).

This strategy has been shown to prevent ants from recognizing trophobiont treehoppers as prey (Silveira et al., 2010) and to reduce ant attacks even in the absence of honeydew rewards (Wang et al., 2018). However, to our knowledge, within Lycaenidae, chemical camouflage has only been demonstrated for the entomophagous caterpillars of Feniseca tarquinius (Fabricius), which have a similar lipid composition to that of their aphid prey, which are mutualistic with ants (Youngsteadt \& DeVries, 2005; Lohman et al., 2006). Silveira et al. (2010) suggested that chemical camouflage could also occur with anttended caterpillars and that this strategy could function as insect analogs of extrafloral nectaries for ants. Thus, this is the first evidence of chemical camouflage among trophobiont caterpillars. It is known that ants may prey on trophobiont species that produce less honeydew (Sakata et al., 1995), and that lycaenid caterpillars can use their secretions to appease the aggressive behavior of ants (Hojo et al., 2015).

Nonetheless, our results suggest that trophobiotic caterpillars can use an additional CHC-mediated strategy through chemical background matching even when they are unable to secrete honeydew. This occurs either because they are in the second instar when their DNOs, which produce nutritious secretions for ants, are not functional (see Fiedler, 1991; Kaminski et al., 2010a) or when they are in the pupal stage when DNOs are not retained (Mizuno et al., 2018). Indeed, some of the highest similarity values between caterpillars and host plants found in the present study were for A. strophius, a commensal 
277 lycaenid pupa Lycaeides argyrognomon (Berstrasser) contains not only CHCs but also

278

279

several long-chain aliphatic aldehydes that suppress ant aggression even after certain antorgans are non-functional (Mizuno et al., 2018).

Moreover, myrmecophilous lycaenid caterpillars have several adaptations, such as chemical defense using exocrine glands, hairiness, thickened larval cuticle, and/or construction of silken shelters, that avoid ant aggression (Malicky, 1970; Pierce et al., 2002). They also have ant-associated organs, such as pore cupola organs (PCOs), which supposedly secrete substances to pacify ants, tentacle organs (TOs) and DNO (Pierce et al., 2002). Lycaenid caterpillars with a specialized parasitic lifestyle may use chemical or acoustic mimicry as well (e.g. Nash et al., 2008; Barbero et al., 2009). However, the low degree of similarity between the $\mathrm{CHC}$ profiles of the caterpillars and ants studied here discards the hypothesis of this kind of chemical mimicry in facultative myrmecophilous interactions.

On the other hand, lycaenids are also benefited by ant protection and grooming (Hölldobler \& Wilson, 1990; Fiedler et al., 1996; Hojo et al., 2014b) and ants may use the non-congruent CHCs of Narathura japonica (Murray) to learn how to recognize this mutualistic partner whereas they do not do the same with the non-ant-associated lycaenid, Lycaena phlaeas (Linnaeus) (Hojo et al., 2014b). According to Hojo et al. (2014a) multiple chemical signatures, not only CHCs, may be important for a myrmecophilous caterpillar to exploit ants. Our study found high SIs among lycaenid species in unrelated genera. This convergence neither provides chemical camouflage on host plants nor chemical mimicry with tending ants. Thus, we propose 'chemical conspicuousness' as a strategy mediated by $\mathrm{CHCs}$ in myrmecophilous caterpillars. In this scenario, we can hypothesize the existence of Müllerian mimicry rings between myrmecophilous species with functional DNO - i.e. an honest signal between true mutualistic partners (Rossato 
\& Kaminski, 2019). Batesian mimicry could also occur when caterpillars that invest little energy in secretions mimic CHCs of conspicuous caterpillars that secrete better caloric rewards for ants. A similar scenario proposed by Oliver \& Stein (2011), was that protection by tending ants. Extensive comparative studies can reveal whether these chemical strategies do indeed occur at the community level.

The present study, along with others, reinforce the selective importance of chemical strategy allowing caterpillars to coexist with ants on plants. In multimodal systems with signals and cues between caterpillars and ants (see Casacci et al., 2019), CHC composition can play a key adaptive role in decreasing ant attacks and increasing caterpillar protection and, consequently, survival. Myrmecophilous caterpillar assemblages can be quite rich in species that use different plant resources that vary in terms of nutritional quality and enemy-free space (Seufert \& Fiedler, 1996; Rodrigues et al., 2010; Silva et al., 2014). Our study adds a new adaptive layer in the form of variation in the degree of similarity and camouflage efficiency that different host plants can offer myrmecophilous caterpillars. We hope that our study can serve as an incentive for further studies of the chemical interface of caterpillar-ant-plant interactions.

\section{Acknowledgments}

323 We thank Laboratório Síncrotron for allowing us to work in its area of cerrado, and Instituto de Botânica de São Paulo for granting permission to work at Reserva Biológica 
327 chemical interface of plant-ant-butterfly interactions. Daniela Rodrigues and Adilson

328 Moreira kindly assisted with the fieldwork. We are grateful to Sabrina C. Thiele for

329 providing the photo of Michaelus thordesa and to Fábio S. do Nascimento, Geraldo L. G.

330 Soares and Viviane G. Ferro for critically reviewing the manuscript. This study was

331 financed by Coordenação de Aperfeiçoamento de Pessoal de Nível Superior - Brasil

332 (CAPES) - Finance Code 001 as a PhD grant to LDL. JRT acknowledges grants from

333 Fundação de Amparo à Pesquisa do Estado de São Paulo (FAPESP) (2011/17708-0) and

334 Conselho Nacional de Pesquisa (CNPq) (2009/304473-0). LAK acknowledges grants

335 from CNPq (140183/2006-0), FAPESP (10/51340-8), PNPD-CAPES, and the National

336 Geographic Society (\#WW-224R-17).

\section{Contribution of authors}

339 All authors contributed to the study conception and design. LDL carried out the statistical analyses and wrote the manuscript. JRT carried out the chemical analyses and drafted the study. LAK collected the organisms, coordinated the study and critically revised the manuscript. All authors gave final approval for publication.

\section{Conflicts of interest}

345 The authors declare they have no conflicts of interest.

\section{Data availability statement}

The data that support the findings of this study are openly available at

https://doi.org/10.6084/m9.figshare.12584765. 


\section{References}

Akino, T. (2005) Chemical and behavioral study on the phytomimetic giant geometer Biston robustum Butler (Lepidoptera: Geometridae). Applied Entomology and Zoology, 40, 497-505. https://doi.org/10.1303/aez.2005.497.

Akino, T. (2008) Chemical strategies to deal with ants: a review of mimicry, camouflage, propaganda, and phytomimesis by ants (Hymenoptera: Formicidae) and other arthropods. Myrmecological News, 11, 173-181.

Akino, T., Nakamura, K.-i. \& Wakamura, S. (2004) Diet-induced chemical phytomimesis by twig-like caterpillars of Biston robustum Butler (Lepidoptera: Geometridae). Chemoecology, 14, 165-174. https://doi.org/10.1007/s00049-004-0274-4.

Alves-Silva, E., Bächtold, A., Barônio, G.J. \& Del-Claro, K. (2013) Influence of Camponotus blandus (Formicinae) and flower buds on the occurrence of Parrhasius polibetes (Lepidoptera: Lycaenidae) in Banisteriopsis malifolia (Malpighiaceae). Sociobiology, 60, 30-34.

Bächtold, A. (2014) A comunidade de borboletas licenídeos de uma área de cerrado: especificidade de dieta, interações ecológicas e seleção de plantas hospedeiras. Dissertation, Universidade de São Paulo, Brazil.

Bächtold, A., Alves-Silva, E., Kaminski, L.A. \& Del-Claro, K. (2014) The role of tending ants in host plant selection and egg parasitism of two facultative myrmecophilous butterflies. Naturwissenschaften, 101, 913-919. https://doi.org/10.1007/s00114-014$1232-9$.

Barbero, F., Thomas, J.A., Bonelli, S., Balletto, E. \& Schönrogge, K. (2009) Queen ants make distinctive sounds that are mimicked by a butterfly social parasite. Science, $\mathbf{3 2 3}$, 782-785. https://doi.org/10.1126/science.1163583. 
376 Budzikiewicz, H., Djerassi, C. \& Williams, D.H. (1967) Mass spectrometry of organic compounds. Holden-Day Inc, San Francisco, USA.

378 Carlson, D.A., Geden, C.J. \& Bernier, U.R. (1999) Identification of pupal exuviae of 379 Nasonia vitripennis and Muscidifurax raptorellus parasitoids using cuticular hydrocarbons.

Biological

Control,

15 ,

97-106. https://doi.org/10.1006/bcon.1999.0708.

Carlson, D.A., Offor, I.I., El Messoussi, S., Matsuyama, K., Mori, K. \& Jallon, J-.M. (1998) Sex pheromone of Glossina tachinoides: isolation, identification and synthesis. https://doi.org/10.1023/A:1020967918594.

Casacci, L.P., Bonelli, S., Balletto, E. \& Barbero, F. (2019) Multimodal signaling in myrmecophilous butterflies. Frontiers in Ecology and Evolution, 7, 454. https://doi.org/10.3389/fevo.2019.00454.

Clarke, K.R. (1993) Non-parametric multivariate analyses of changes in community structure. Australian Journal of Ecology, 18, 117-143.

Daniels, H., Gottsberger, G. \& Fiedler, K. (2005) Nutrient composition of larval nectar secretions from three species of myrmecophilous butterflies. Journal of Chemical Ecology, 31, 2805-2821. https://doi.org/10.1007/s10886-005-8395-y.

DeVries, P.J. (1990) Enhancement of symbioses between butterfly caterpillars and ants by vibrational communication.

Science,

248 , 1104-1106. 
Espelie, K.E., Bernays, E.A. \& Brown, J.J. (1991) Plant and insect cuticular lipids serve as behavioral cues for insects. Archives of Insect Biochemistry and Physiology, 17, 223-233. https://doi.org/10.1002/arch.940170406.

Faynel, C., Bénéluz, F., Brûlé, S. \& Fernandez, S. (2017) Dioclea guianensis et Dioclea virgata (Fabaceae): plantes hôtes de nombreux Lycaenidae et Riodinidae en Guyane. Exemples de polychromatisme larvaire cryptique (Lepidoptera). Revue de l'Association Roussillonnaise d'Entomologie, 26, 135-143.

Fiedler, K. (1991) Systematic, evolutionary, and ecological implications of myrmecophily within the Lycaenidae (Insecta: Lepidoptera: Papilionoidea). Bonner Zoologische Monographien, 31, 1-210.

Fiedler, K., Hölldobler, B. \& Seufert, P. (1996) Butterflies and ants: the communicative domain. Experientia, 52, 14-24. https://doi.org/10.1007/BF01922410.

Fischer, M.K., Hoffmann, K.H. \& Völkl, W. (2001) Competition for mutualists in an anthomopteran interaction mediated by hierarchies of ant attendance. Oikos, 92, 531-541. https://doi.org/10.1034/j.1600-0706.2001.920314.x.

Floren, A., Biun, A. \& Linsenmair, K.E. (2002) Arboreal ants as key predators in tropical lowland rainforest trees. Oecologia, 131, 137-144. https://doi.org/10.1007/s00442002-0874-z.

Francis, G.W. \& Veland, K. (1981) Alkylthiolation for the determination of double-bond positions in linear alkenes. Journal of Chromatography, 219, 379-384. https://doi.org/10.1016/S0021-9673(00)80381-7.

Gibernau, M. \& Dejean, A. (2001) Ant protection of a Heteropteran trophobiont against a parasitoid wasp. Oecologia, 126, 53-57. https://doi.org/10.1007/s004420000479. 
420 Hammer, Ø., Harper, D.A.T. \& Ryan, P.D. (2001) PAST: Paleontological Statistics

421 Software Package for Education and Data Analysis. Palaeontologia Electronica, 4, 1-

4229.

423 Hojo, M.K., Pierce, N.E. \& Tsuji, K. (2015) Lycaenid caterpillar secretions manipulate attendant ant behavior. Current Biology, 25, 2260-2264. http://doi.org/10.1016/j.cub.2015.07.016.

Hojo, M.K., Yamaguchi, S., Akino, T. \& Yamaoka, R. (2014a) Adoption of lycaenid https://doi.org/10.1111/ens.12041.

Hojo, M.K., Yamamoto, A., Akino, T., Tsuji, K. \& Yamaoka, R. (2014b) Ants use partner specific odors to learn to recognize a mutualistic partner. Plos One, 9, e86054. https://doi.org/10.1371/journal.pone.0086054.

Hölldobler, B. \& Wilson, E.O. (1990) The Ants. The Belknap Press of Harvard University Press, Cambridge, USA.

Howard, R.W. (2001) Cuticular hydrocarbons of adult Pteromalus cerealellae (Hymenoptera: Pteromalidae) and two larval hosts, Angoumois grain moth (Lepidoptera: Gelechiidae) and cowpea weevil (Coleptera: Bruchidae). Annals of the 8746(2001)094[0152:CHOAPC]2.0.CO;2.

Kaminski, L.A. \& Freitas, A.V.L. (2010) Natural history and morphology of immature stages of the butterfly Allosmaitia strophius (Godart) (Lepidoptera: Lycaenidae) on flower buds of Malpighiaceae. Studies on Neotropical Fauna and Environment, 45, 11-19. https://doi.org/10.1080/01650520903495826. 
444 Kaminski, L.A., Freitas, A.V.L. \& Oliveira, P.S. (2010a) Interaction between 445 mutualisms: ant-tended butterflies exploit enemy-free space provided by ant446 treehopper associations. American Naturalist, 176, 322-334. 447 http://doi.org/10.1086/655427.

448 Kaminski, L.A., Rodrigues, D. (2011) Species-specific levels of ant attendance mediate 449 performance costs in a facultative myrmecophilous butterfly. Physiological Entomology, 36, 208-214. https://doi.org/10.1111/j.1365-3032.2011.00785.x.

Kaminski, L.A., Rodrigues, D. \& Freitas, A.V.L. (2012) Immature stages of Parrhasius polibetes (Lepidoptera: Lycaenidae): host plants, tending ants, natural enemies and morphology. Journal of Natural History, 46, $\quad 645-667$. http://doi.org/10.1080/00222933.2011.651630.

Kaminski, L.A., Thiele, S.C., Iserhard, C.A., Romanowski, H.P. \& Moser, A. (2010b) Natural history, new records, and notes on the conservation status of Cyanophrys bertha (Jones) (Lepidoptera: Lycaenidae). Proceedings of the Entomological Society of Washington, 112, 54-60. https://doi.org/10.4289/0013-8797-112.1.54.

Krebs, C.J. (1999) Ecological Methodology. Addison Wesley Longman, Menlo Park, 460 USA.

Lange, D., Calixto, E.S., Rosa, B.B., Sales, T.A. \& Del-Claro, K. (2019) Natural history and ecology of foraging of the Camponotus crassus Mayr, 1862 (Hymenoptera: Formicidae). Journal of Natural History, 53, 1737-1749. https://doi.org/10.1080/00222933.2019.1660430. Switzerland. 
468 Lohman, D.J., Liao, Q. \& Pierce, N.E. (2006) Convergence of chemical mimicry in a

469 guild of aphid predators. Ecological Entomology, 31, 41-51.

$470 \quad$ https://doi.org/10.1111/j.0307-6946.2006.00758.x.

471 Malicky, H. (1970) New aspects on the association between lycaenid larvae (Lycaenidae)

472 and ants (Formicidae, Hymenoptera). Journal of the Lepidopterists' Society, 24, 190-

473202.

474 Massuda, K.F. \& Trigo, J.R. (2014) Hiding in plain sight: cuticular compound profile 475 matching conceals a larval tortoise beetle in its host chemical cloud. Journal of 476 Chemical Ecology, 40, 341-354. https://doi.org/10.1007/s10886-014-0424-2.

477 Menéndez, R., Marrero, D., Más, R., Fernández, I., González, L. \& González, R.M. 478 (2005) In vitro and in vivo study of octacosanol metabolism. Archives of Medical Research, 36, 113-119. https://doi.org/10.1016/j.arcmed.2004.12.006.

Mizuno, T., Hagiwara, Y., Akino, T. (2018) Chemical tactic of facultative 182. https://doi.org/10.1007/s00049-018-0270-8.

Monteiro, R.F. (1991) Cryptic larval polychromatism in Rekoa marius Lucas and $R$. palegon Cramer (Lycaenidae: Theclinae). Journal of Research on the Lepidoptera, 29, $77-84$.

Nash, D.R., Als, T.D., Maile, R., Jones, G.R. \& Boomsma, J.J. (2008) A mosaic of chemical coevolution in a large blue butterfly. Science, 319, 88-90. https://doi.org/10.1126/science.1149180.

489 Nelson, D.R., Dillwith, J.W. \& Blomquist, G.J. (1981) Cuticular hydrocarbons of the house fly, Musca domestica. Insect Biochemistry, 11, 187-197. 
492 Oliveira-Filho, A.T. \& Ratter, J.A. (2002) Vegetation physiognomies and woody flora of the Cerrado biome. The cerrados of Brazil: Ecology and Natural History of a University Press, New York, USA.

Oliver, J.C. \& Stein, L.R. (2011) Evolution of influence: signaling in a lycaenid-ant interaction. Evolutionary Ecology, 25, 1205-1216. https://doi.org/10.1007/s10682011-9478-6.

Pierce, M.P. (2019) The ecological and evolutionary importance of nectar-secreting galls. Ecosphere, 10, e02670. https://doi.org/10.1002/ecs2.2670.

Pierce, N.E., Braby, M.F., Heath, A., Lohman, D.J., Mathew, J., Rand, D.B. \& Travassos, M.A. (2002) The ecology and evolution of ant association in the Lycaenidae (Lepidoptera). Annual Review of Entomology, 47, 733-771.

Piskorski, R., Trematerra, P. \& Dorn, S. (2010) Cuticular hydrocarbon profiles of codling moth larvae, Cydia pomonella (Lepidoptera: Tortricidae), reflect those of their host plant species. Biological Journal of the Linnean Society, 101, 376-384. https://doi.org/10.1111/j.1095-8312.2010.01511.x.

Pomonis, J.G. (1989) Cuticular hydrocarbons of the screwworm, Cochliomyia hominivorax (Diptera: Calliphoridae). Isolation, identification and quantification as a function of age, sex and irradiation. Journal of Chemical Ecology, 15, 2301-2317. and its host plant: a way to make prey undetectable for predatory ants?. Journal of Chemical Ecology, 31, 2551-2561. https://doi.org/10.1007/s10886-005-7613-y. 
516 Pringle, E.G. (2020) Ant-Hemiptera associations. Encyclopedia of Social Insects (ed. by C. Starr), pp. 1-5. Springer Nature, Cham, Switzerland.

Ranganathan, Y., Bessière, J.-M. \& Borges, R.M. (2015) A coat of many scents: cuticular hydrocarbons in multitrophic interactions of fig wasps with ants. Acta Oecologica, 67, 24-33. https://doi.org/10.1016/j.actao.2015.05.007.

Rico-Gray, V. \& Oliveira, P.S. (2007) The Ecology and Evolution of Ant-plant Interactions. University of Chicago Press, Chicago, USA.

Robbins, R.K. (2004) Introduction to the checklist of Eumaeini (Lycaenidae). Atlas of Neotropical Lepidoptera. Checklist: Part 4A. Hesperioidea - Papilionoidea, vol 5A

Robbins, R.K. \& Aiello, A. (1982) Foodplant and oviposition records for Panamanian Lycaenidae and Riodinidae. Journal of the Lepidopterists' Society, 36, 65-75.

Rossato, D.O. \& Kaminski, L.A. (2019) Müllerian mimicry. Encyclopedia of Animal Cham, Switzerland.

Rodrigues, D., Kaminski, L.A., Freitas, A.V.L. \& Oliveira, P.S. (2010) Trade-offs underlying polyphagy in a facultative ant-tended florivorous butterfly: the role of host plant quality and enemy-free space. Oecologia, 16, 719-728. https://doi.org/10.1007/s00442-010-1626-0.

Ruxton, G.D., Sherratt, T.N. \& Speed, M.P. (2004) Avoiding attack: the evolutionary ecology of crypsis, warning signals and mimicry. Oxford University Press, New York, USA. 
539 Sakata, H. (1995) Density-dependent predation of the ant Lasius niger (Hymenoptera:

540 Formicidae) on two attended aphids Lachnus tropicalis and Myzocallis kuricola

541 (Homoptera: Aphididae). Researches on Population Ecology, 37, 159-164.

$542 \quad$ https://doi.org/10.1007/BF02515816.

543 Seufert, P., Fiedler, K. (1996) The influence of ants on patterns of colonization and

544 establishment within a set of coexisting lycaenid butterflies in a south-east Asian

545 tropical rain forest. Oecologia, 106, 127-136. https://doi.org/10.1007/BF00334414.

546 Silva, N.A.P., Duarte, M., Araújo, E.B. \& Morais, H.C. (2014) Larval biology of 547 anthophagous Eumaeini (Lepidoptera: Lycaenidae, Theclinae) in the Cerrado of 548 central Brazil. Journal of Insect Science, 14, 2014. 549 https://doi.org/10.1093/jisesa/ieu046.

550 Silveira, H.C.P., Oliveira, P.S. \& Trigo, J.R. (2010) Attracting predators without falling 551 prey: chemical camouflage protects honeydew-producing treehoppers from ant predation. American Naturalist, 175, 261-268. https://doi.org/10.1086/649580.

553 Vidal, M.C. \& Murphy, S.M. (2018) Bottom-up vs. top-down effects on terrestrial insect 554 herbivores: a meta-analysis. Ecology Letters, 21, 138-150. https://doi.org/10.1111/ele.12874.

von Beeren, C., Pohl, S. \& Witte, V. (2012) On the use of adaptive resemblance terms in chemical ecology. Psyche, 2012, 635761. https://doi.org/10.1155/2012/635761.

558 Wang, B., Lu, M., Cook, J.M., Yang, D.-R., Dunn, D.W. \& Wang, R.-W. (2018)

559 Chemical camouflage: a key process in shaping an ant-treehopper and fig-fig wasp 560 mutualistic network. Scientific Reports, 8, 1833. https://doi.org/10.1038/s41598-018$56120310-7$. 
562 Wang, M.-F., Lian, H.-Z., Mao, L., Zhou, J.-P., Gong, H.-J., Qian, B.-Y., Fang, Y. \& Li,

563 J. (2007) Comparison of various extraction methods for policosanol from rice bran

564 wax and establishment of chromatographic fingerprint of policosanol. Journal of

565 Agricultural and Food Chemistry, 55, 5552-5558. https://doi.org/10.1021/jf063623q.

566 Youngsteadt, E. \& DeVries, P.J. (2005) The effects of ants on the entomophagous

567 butterfly caterpillar Feniseca tarquinius, and the putative role of chemical camouflage

568 in the Feniseca-ant interaction. Journal of Chemical Ecology, 31, 2091-2109. https://doi.org/10.1007/s10886-005-6079-2. 
Table 1. Morisita's similarity index (mean \pm standard error) of the shared cuticular hydrocarbons of lycaenid caterpillars, host plants, and tending ants. Similarity values $>0.8$ in bold

\begin{tabular}{|c|c|c|c|c|c|c|c|c|c|c|c|c|}
\hline \multirow[b]{2}{*}{$\begin{array}{l}\text { Lycaenid } \\
\text { caterpillars }\end{array}$} & \multicolumn{3}{|c|}{ Host plants } & \multicolumn{7}{|c|}{ Lycaenid caterpillars } & \multicolumn{2}{|c|}{ Tending ants } \\
\hline & $\begin{array}{l}\text { Byrsonima } \\
\text { intermedia }\end{array}$ & $\begin{array}{c}\text { Pyrostegia } \\
\text { venusta }\end{array}$ & $\begin{array}{c}\text { Schefflera } \\
\text { vinosa }\end{array}$ & $\begin{array}{c}\text { Allosmaitia } \\
\text { strophius }\end{array}$ & $\begin{array}{c}\text { Chalybs } \\
\text { hassan }\end{array}$ & $\begin{array}{c}\text { Michaelus } \\
\text { thordesa }\end{array}$ & $\begin{array}{c}\text { Parrhasius } \\
\text { polibetes (S) }\end{array}$ & $\begin{array}{c}\text { Parrhasius } \\
\text { polibetes }(\mathrm{L})\end{array}$ & $\begin{array}{l}\text { Rekoa } \\
\text { marius }\end{array}$ & $\begin{array}{l}\text { Rekoa } \\
\text { stagira }\end{array}$ & $\begin{array}{c}\text { Camponotus } \\
\text { blandus }\end{array}$ & $\begin{array}{c}\text { Camponotus } \\
\text { crassus }\end{array}$ \\
\hline $\begin{array}{l}\text { Allosmaitia } \\
\text { strophius (L)* }\end{array}$ & $0.93 \pm 0.02$ & - & - & - & $0.39 \pm 0.00$ & $0.25 \pm 0.01$ & $0.85 \pm 0.00$ & $0.34 \pm 0.01$ & $0.39 \pm 0.05$ & $0.95 \pm 0.00$ & $0.03 \pm 0.00$ & $0.08 \pm 0.00$ \\
\hline $\begin{array}{l}\text { Chalybs hassan } \\
\text { (L)** }\end{array}$ & - & - & 0.34 & $0.39 \pm 0.00$ & - & 0.76 & 0.54 & $0.78 \pm 0.02$ & $0.62 \pm 0.03$ & 0.54 & 0.09 & 0.09 \\
\hline $\begin{array}{l}\text { Michaelus } \\
\text { thordesa (L) }\end{array}$ & - & $0.55 \pm 0.00$ & - & $0.25 \pm 0.01$ & 0.76 & - & 0.36 & $0.80 \pm 0.06$ & $0.58 \pm 0.01$ & 0.41 & 0.05 & 0.04 \\
\hline $\begin{array}{l}\text { Parrhasius } \\
\text { polibetes }(\mathrm{S})^{*}\end{array}$ & $0.90 \pm 0.03$ & - & - & $0.85 \pm 0.00$ & 0.54 & 0.36 & - & $0.51 \pm 0.03$ & $0.54 \pm 0.11$ & 0.92 & 0.06 & 0.13 \\
\hline $\begin{array}{l}\text { Parrhasius } \\
\text { polibetes (L) }\end{array}$ & $0.44 \pm 0.04$ & $0.60 \pm 0.02$ & 0.27 & $0.34 \pm 0.01$ & $0.78 \pm 0.02$ & $0.80 \pm 0.06$ & $0.51 \pm 0.03$ & $0.77 \pm 0.05$ & $0.66 \pm 0.01$ & $0.51 \pm 0.03$ & $0.14 \pm 0.02$ & $0.10 \pm 0.01$ \\
\hline $\begin{array}{l}\text { Rekoa marius } \\
\text { (L) }\end{array}$ & - & $\mathbf{0 . 8 2} \pm 0.08$ & 0.23 & $0.39 \pm 0.05$ & $0.62 \pm 0.03$ & $0.58 \pm 0.01$ & $0.54 \pm 0.11$ & $0.66 \pm 0.01$ & - & $0.53 \pm 0.09$ & $0.06 \pm 0.01$ & $0.15 \pm 0.04$ \\
\hline $\begin{array}{l}\text { Rekoa stagira } \\
\text { (L) }\end{array}$ & $0.94 \pm 0.02$ & - & - & $0.95 \pm 0.00$ & 0.54 & 0.41 & 0.92 & $0.51 \pm 0.03$ & $0.53 \pm 0.09$ & - & 0.03 & 0.10 \\
\hline
\end{tabular}


bioRxiv preprint doi: https://doi org/10.1101/2020.06 29.178319. this version posted July 24, 2020. The copyright holder for this preprint (which was not certified by peer review) is the author/funder, who has granted bioRxiv a license to display the preprint in perpetuity. It is made available under aCC-BY-NC-ND 4.0 International license.

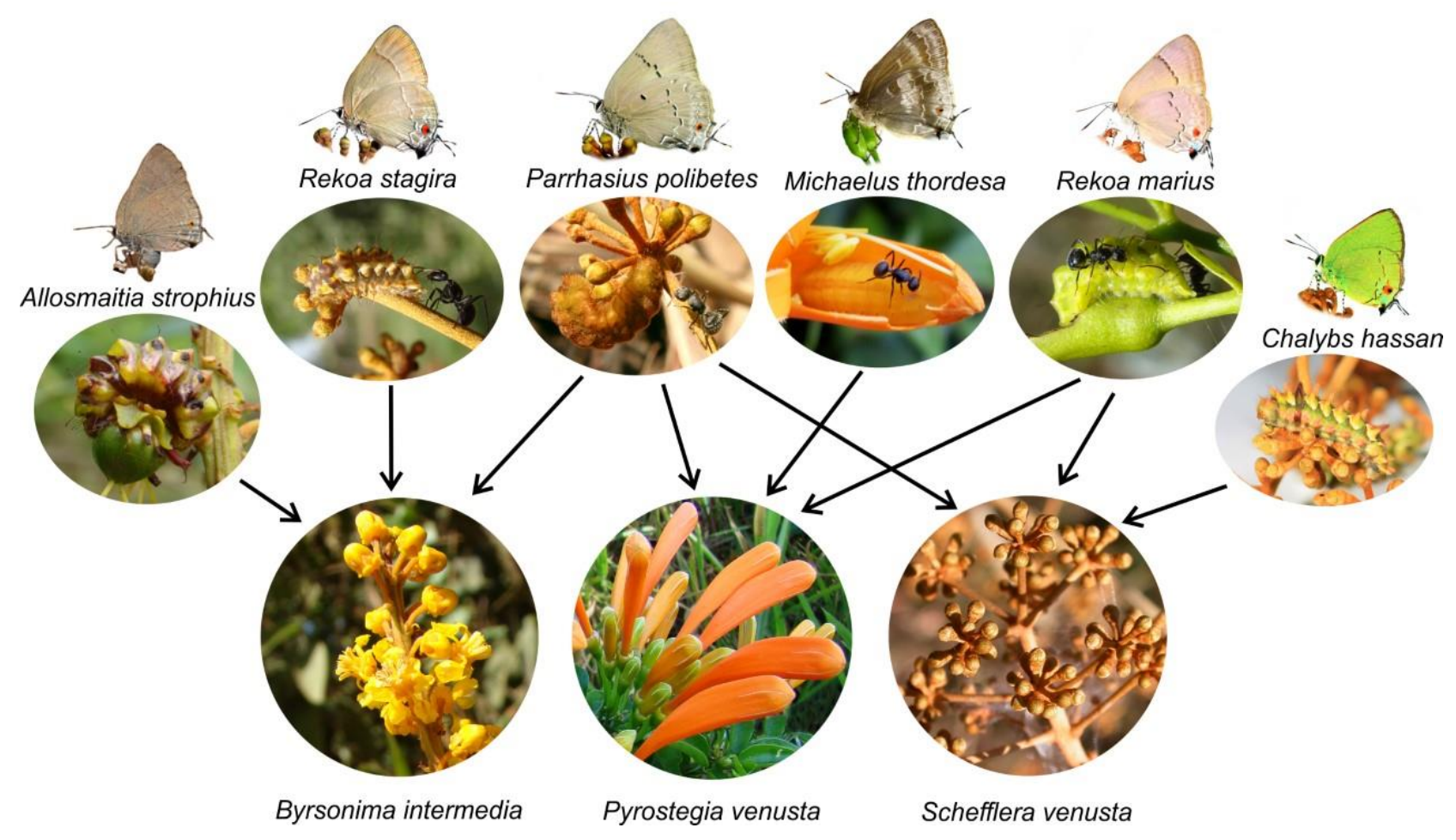

Fig. 1. 
bioRxiv preprint doi: https://doi org/101101/2020 06 29.178319: this version posted July 24,2020 . The copyright holder for this preprin (which was not certified by peer review) is the author/funder, who has granted bioRxiv a license to display the preprint in perpetuity. It is made available under aCC-BY-NC-ND 4.0 International license.

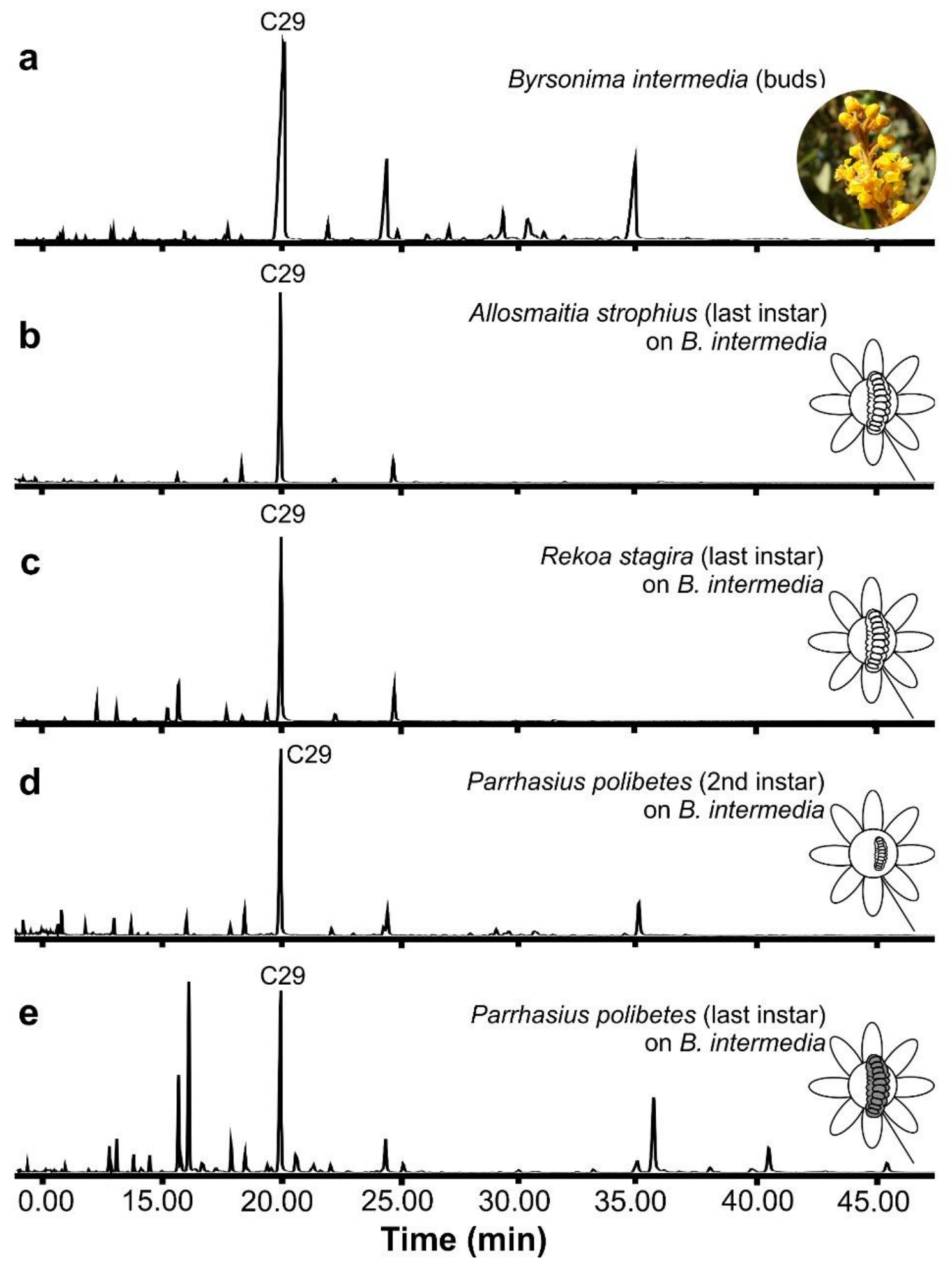

Fig. 2. 


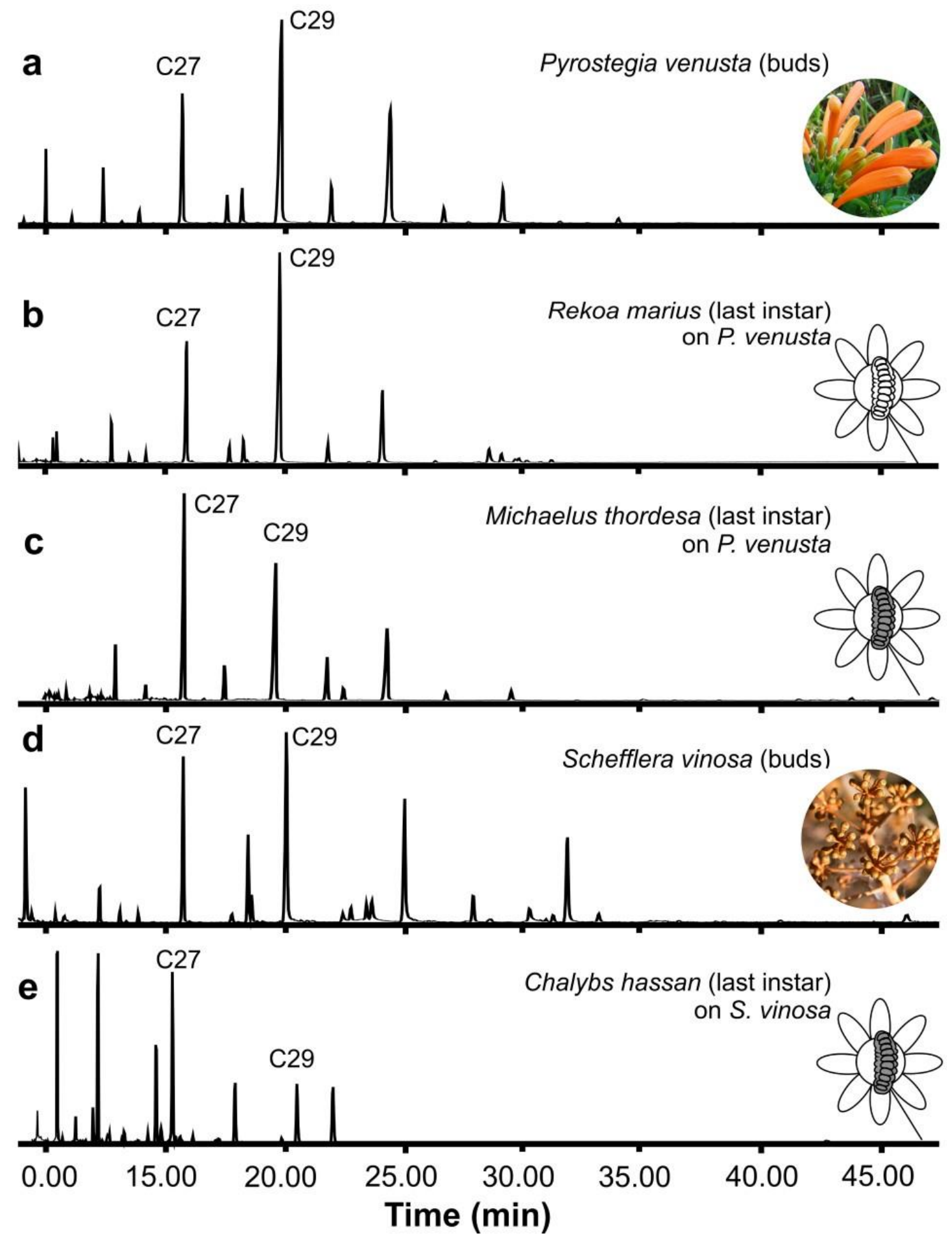

Fig. 3. 
bioRxiv preprint doi: https://doi.org/10.1101/2020.06.29.178319. this version posted July 24, 2020. The copyright holder for this preprint (which was not certified by peer review) is the author/funder, who has granted bioRxiv a license to display the preprint in perpetuity. It is made available under aCC-BY-NC-ND 4.0 International license.

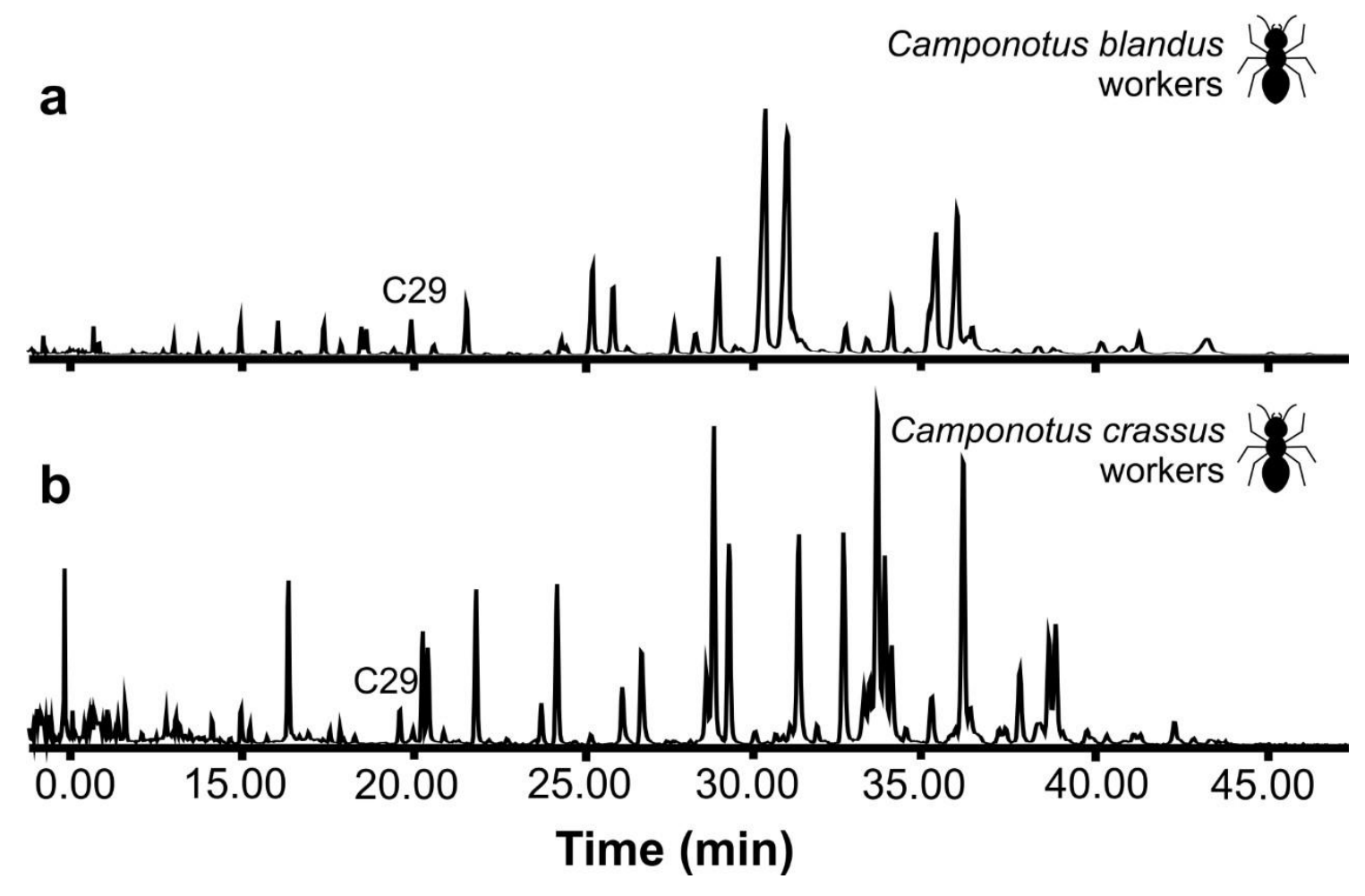

Fig. 4. 
bioRxiv preprint doi: https://doi.org/101101/2020.06 29.178319; this version posted July 24, 2020. The copyright holder for this preprint (which was not certified by peer review) is the author/funder, who has granted bioRxiv a license to display the preprint in perpetuity. It is made available under aCC-BY-NC-ND 4.0 International license.

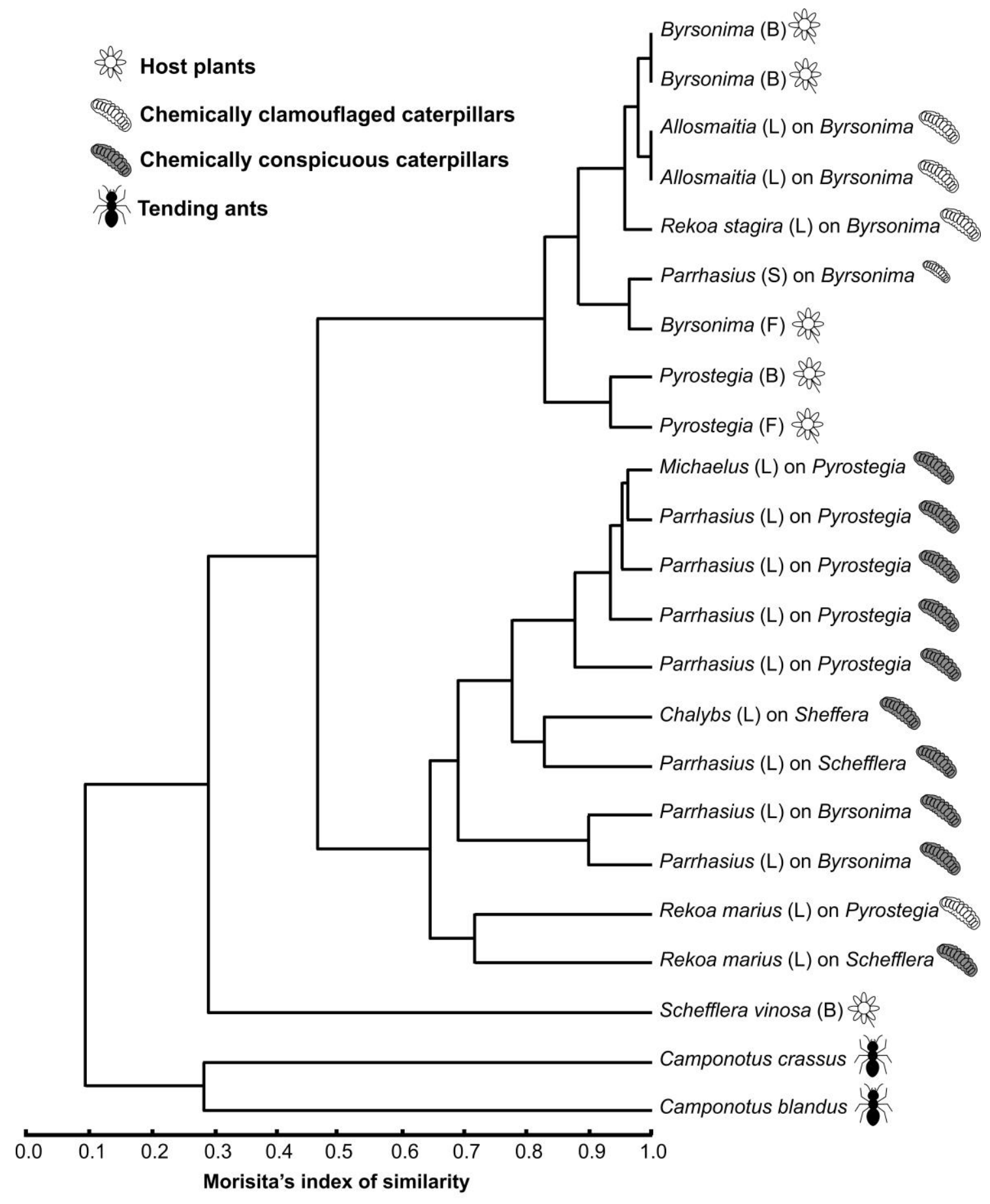

\section{Fig. 5.}


bioRxiv preprint doi: https://doi org/101101/2020.06 29.178319; this version posted July 24, 2020 . The copyright holder for this preprint (which was not certified by peer review) is the author/funder, who has granted bioRxiv a license to display the preprint in perpetuity. It is made available under aCC-BY-NC-ND 4.0 International license.

\section{Figure legends}

Fig. 1. Multitrophic systems studied involving a guild of six facultative myrmecophilous caterpillars (Lepidoptera: Lycaenidae), tending ants (Hymenoptera: Formicidae) and host plant species of three families (Malpighiaceae, Bignoniaceae and Araliaceae) respectively. Photos of Michaelus thordesa by Sabrina Thiele $($ )

Fig. 2. Chromatograms of cuticular compounds of Byrsonima intermedia

(Malpighiaceae) buds (a) and of associated facultative myrmecophilous caterpillars (Lepidoptera: Lycaenidae) (b-e). (b) last instar of Allosmaitia strophius, (c) last instar of Rekoa stagira, (d) second instar of Parrhasius polibetes, and (e) last instar of $P$. polibetes. Schematic white-colored caterpillars represent cases of the 'chemical camouflage' strategy ( similarity $>80 \%$ ) while gray-colored caterpillars represent cases of the 'chemical conspicuousness' strategy

Fig. 3. Chromatograms of the cuticular compounds of host plants (a, d) and associated facultative myrmecophilous caterpillars (Lepidoptera: Lycaenidae) (b-c, e). (a) Pyrostegia venusta (Bignoniaceae) buds, (b) last instar of Rekoa marius on $P$. venusta, (c) last instar of Michaelus thordesa on P. venusta, (d) buds of Schefflera vinosa (Araliaceae), and (e) last instar of Chalybs hassan on S. vinosa. Schematic whitecolored caterpillar represent cases of the 'chemical camouflage' strategy ( similarity > $80 \%$ ) while gray-colored caterpillars represent cases of the 'chemical conspicuousness' strategy

Fig. 4. Chromatograms of the cuticular compounds of tending ants (Hymenoptera: Formicidae). (a) Camponotus blandus workers, (b) Camponotus crassus workers 
hydrocarbons of facultative myrmecophilous caterpillars (Lepidoptera: Lycaenidae),

host plants and tending ants. $\mathrm{B}=$ bud; $\mathrm{F}=$ flower; $\mathrm{L}=$ last instar; $\mathrm{S}=$ second instar 


\section{Supporting Information}

Table S1. Relative abundance (\%) of cuticular compounds of the host plant Byrsonima intermedia, lycaenid caterpillars and ants. Only compounds and values above 5\% are shown

\begin{tabular}{|c|c|c|c|c|c|c|c|c|c|c|c|c|}
\hline Compounds & $\begin{array}{l}\text { Retention } \\
\text { Index }\end{array}$ & $\begin{array}{l}\text { B. intermedia } \\
(\mathrm{Bud})\end{array}$ & $\begin{array}{l}\text { B. intermedia } \\
\text { (Bud) }\end{array}$ & $\begin{array}{l}\text { B. intermedia } \\
\text { (Flo) }\end{array}$ & $\begin{array}{l}\text { A. strophius } \\
\text { (last) }\end{array}$ & $\begin{array}{l}\text { A. strophius } \\
\text { (last) }\end{array}$ & $\begin{array}{c}\text { P. polibetes } \\
(2 \mathrm{nd})\end{array}$ & $\begin{array}{c}\text { P. polibetes } \\
\text { (last) }\end{array}$ & $\begin{array}{c}\text { P. polibetes } \\
\text { (last) }\end{array}$ & $\begin{array}{l}\text { R. stagira } \\
\text { (last) }\end{array}$ & $\begin{array}{c}C . \\
\text { blandus }\end{array}$ & $\begin{array}{c}C . \\
\text { crassus } \\
\end{array}$ \\
\hline $\mathrm{C}_{25}$ & 2500 & - & - & - & - & - & - & - & 11.84 & - & - & - \\
\hline $\mathrm{x}-\mathrm{C}_{27: 1}$ & 2674 & - & - & - & - & - & - & 8.41 & 11.98 & - & - & - \\
\hline $\mathrm{C}_{27}$ & 2700 & - & - & - & - & - & - & 17.04 & 13.47 & 10.15 & - & - \\
\hline Squalene & 2828 & - & - & - & 5.73 & 7.19 & 5.22 & - & - & - & - & - \\
\hline $\mathrm{C}_{29}$ & 2900 & 69.91 & 70.52 & 49.65 & 80.25 & 78.47 & 47.05 & 22.19 & 15.12 & 60.71 & - & - \\
\hline $\mathrm{C}_{31}$ & 3100 & 21.41 & 22.48 & 13.76 & 10.64 & 11.94 & 6.81 & - & - & 11.90 & - & - \\
\hline $\mathrm{x}: \mathrm{C}_{32: 1}$ & 3183 & - & - & - & - & - & - & - & - & - & - & 8.52 \\
\hline $\mathrm{C}_{32}$ & 3200 & - & - & - & - & - & - & - & - & - & - & 5.49 \\
\hline $\mathrm{x}-\mathrm{C}_{33: 1}$ & 3280 & - & - & - & - & - & - & - & - & - & - & 6.27 \\
\hline $17-, 15-, 13-\mathrm{Me}-\mathrm{C}_{33}$ & 3334 & - & - & - & - & - & - & - & - & - & 16.70 & 6.00 \\
\hline $\begin{array}{l}\text { 15,19-, 13,17-. 9,13-DiMe } \\
\mathrm{C}_{33}\end{array}$ & 3356 & - & - & - & - & - & - & - & - & - & 18.60 & - \\
\hline $\mathrm{x}-\mathrm{C}_{34: 2}$ & 3364 & - & - & - & - & - & - & - & - & - & - & 10.87 \\
\hline $\mathrm{x}-\mathrm{C}_{33: 2}$ & 3462 & - & - & - & - & - & - & - & - & - & - & 8.68 \\
\hline $15-, 13-, 11-, 9-\mathrm{Me}-\mathrm{C}_{35}$ & 3530 & - & - & - & - & - & - & - & - & - & 7.50 & - \\
\hline Unknown triterpen & 3536 & - & - & 18.27 & - & - & 11.20 & - & - & - & - & - \\
\hline 15,19-, 13,17-DiMe-C 35 & 3556 & - & - & - & - & - & - & - & - & - & 9.30 & - \\
\hline $11,16-\mathrm{DiMe}-\mathrm{C}_{35}$ & 3558 & - & - & - & - & - & - & 13.34 & 12.04 & - & - & - \\
\hline Unknown & $?$ & - & - & - & - & - & - & 5.10 & 6.62 & - & 6.67 & 5.21 \\
\hline
\end{tabular}


Table S2. Relative abundance (\%) of cuticular compounds of the host plant Pyrostegia venusta and lycaenid caterpillars. Only compounds and values above 5\% are shown

\begin{tabular}{|c|c|c|c|c|c|c|c|c|c|}
\hline Compounds & $\begin{array}{l}\text { Retention } \\
\text { Index }\end{array}$ & $\begin{array}{c}\text { P.venusta } \\
\text { (Bud) }\end{array}$ & $\begin{array}{l}\text { P. venusta } \\
\text { (Flo) }\end{array}$ & $\begin{array}{l}\text { M. thordesa } \\
\text { (last) }\end{array}$ & $\begin{array}{c}\text { P. polibetes } \\
\text { (last) }\end{array}$ & $\begin{array}{c}\text { P. polibetes } \\
\text { (last) }\end{array}$ & $\begin{array}{c}\text { P. polibetes } \\
\text { (last) }\end{array}$ & $\begin{array}{c}\text { P. polibetes } \\
\text { (last) }\end{array}$ & $\begin{array}{l}\text { R. marius } \\
\text { (last) }\end{array}$ \\
\hline $\mathrm{C}_{23}$ & 2300 & - & - & - & 12.84 & - & 5.56 & 9.58 & 12.00 \\
\hline $\mathrm{C}_{25}$ & 2500 & - & - & 25.66 & 18.39 & 23.53 & 19.55 & 11.17 & 7.06 \\
\hline $\mathrm{C}_{26}$ & 2600 & - & - & 6.07 & - & - & - & - & - \\
\hline $\mathrm{C}_{27}$ & 2700 & 15.02 & 20.18 & 36.09 & 28.69 & 27.76 & 29.67 & 23.72 & 12.71 \\
\hline $\mathrm{C}_{28}$ & 2800 & - & - & 6.52 & - & - & - & - & - \\
\hline Squalene & 2828 & - & - & - & - & 7.72 & - & 12.50 & - \\
\hline $\mathrm{C}_{29}$ & 2900 & 33.28 & 48.37 & 13.03 & 12.22 & 13.76 & 17.50 & 14.75 & 20.09 \\
\hline $\mathrm{C}_{31}$ & 3100 & 23.37 & 16.81 & - & - & - & - & - & 20.66 \\
\hline $\mathrm{C}_{33}$ & 3300 & 5.16 & - & - & - & - & - & - & - \\
\hline $15,19-, 13,17-\mathrm{DiMe}-\mathrm{C}_{35}$ & 3556 & - & - & - & 6.70 & - & - & - & - \\
\hline
\end{tabular}


Table S3. Relative abundance (\%) of cuticular compounds of the host plant Schefflera vinosa and lycaenid caterpillars. Only compounds and values above 5\% are shown

\begin{tabular}{lccccc}
\hline \multicolumn{1}{c}{ Compounds } & $\begin{array}{c}\text { Retention } \\
\text { Index }\end{array}$ & $\begin{array}{c}\text { S.vinosa } \\
(\mathrm{Bud})\end{array}$ & $\begin{array}{c}\text { C. hassan } \\
\text { (last) }\end{array}$ & $\begin{array}{c}\text { P. polibetes } \\
\text { (last) }\end{array}$ & $\begin{array}{c}\text { R. marius } \\
\text { (last) }\end{array}$ \\
\hline Unknown & $?$ & 9.80 & - & - & - \\
$\mathrm{C}_{23}$ & 2300 & - & - & - & 6.67 \\
$\mathrm{x}_{25: 1}$ & 2471 & - & - & - & 20.89 \\
$\mathrm{C}_{25}$ & 2500 & - & - & - & 10.17 \\
$\mathrm{C}_{27}$ & 2700 & 12.91 & 25.13 & 22.60 & 14.43 \\
Squalene & 2828 & 7.00 & 6.09 & - & - \\
$2-$ Me-C 28 & 2861 & - & 7.80 & - & - \\
x-C29:1 & 2873 & - & - & 8.55 & - \\
Hexacosanol & 2899 & 22.00 & - & - & - \\
$\mathrm{C}_{29}$ & 2900 & - & 18.00 & 22.76 & 12.39 \\
$\mathrm{C}_{31}$ & 3100 & - & - & - & 12.39 \\
Otacosanol & 3105 & 13.00 & - & - & - \\
Branched with 35 C & 3326 & - & - & 7.45 & - \\
$15,19-, 13,17-, 9,13-D i M e-C_{33}$ & 3356 & - & - & 8.05 & - \\
Unknown triterpen & 3361 & 10.84 & - & - & - \\
\hline
\end{tabular}


bioRxiv preprint doi: https://doi.org/10.1101/2020.06.29.178319; this version posted July 24, 2020. The copyright holder for this preprint (which was not certified by peer review) is the author/funder, who has granted bioRxiv a license to display the preprint in perpetuity. It is made available under aCC-BY-NC-ND 4.0 International license.

Table S4. One-way ANOSIM comparing the relative proportions of cuticular hydrocarbons of the profiles of lycaenid caterpillars, host plants and workers of the genus Camponotus

\begin{tabular}{ccccccc}
\hline & \multicolumn{2}{c}{ Caterpillars } & \multicolumn{2}{c}{ Ants } & \multicolumn{2}{c}{ Plants } \\
\hline & $\mathrm{R}$ & $\mathrm{P}$ & $\mathrm{R}$ & $\mathrm{P}$ & $\mathrm{R}$ & $\mathrm{P}$ \\
\hline Caterpillars & - & - & 1 & 0.0067 & 0.2094 & 0.0329 \\
Ants & 1 & 0.0067 & - & - & 0.6354 & 0.0768 \\
Plants & 0.2094 & 0.0329 & 0.6354 & 0.0768 & - & - \\
\hline
\end{tabular}


bioRxiv preprint doi: https://doi.org/10.1101/2020.06.29.178319; this version posted July 24, 2020. The copyright holder for this preprint (which was not certified by peer review) is the author/funder, who has granted bioRxiv a license to display the preprint in perpetuity. It is made available under aCC-BY-NC-ND 4.0 International license.

Table S5. One-way ANOSIM comparison between the relative proportions of cuticular hydrocarbons of the profiles of lycaenid caterpillars, host plants and Camponotus workers

\begin{tabular}{cccccccccc}
\hline & \multicolumn{2}{c}{$\begin{array}{c}\text { Commensal } \\
\text { caterpillars }\end{array}$} & \multicolumn{2}{c}{$\begin{array}{l}\text { Mutualistic } \\
\text { caterpillars }\end{array}$} & \multicolumn{2}{c}{ Ants } & \multicolumn{2}{c}{ Plants } \\
\hline & $\mathrm{R}$ & $\mathrm{P}$ & $\mathrm{R}$ & $\mathrm{P}$ & $\mathrm{R}$ & $\mathrm{P}$ & $\mathrm{R}$ & $\mathrm{P}$ \\
\hline $\begin{array}{l}\text { Commensal } \\
\text { caterpillars }\end{array}$ & - & - & 0.744 & 0.0048 & 1 & 0.0924 & -0.08642 & 0.5548 \\
$\begin{array}{l}\text { Mutualistic } \\
\text { caterpillars }\end{array}$ & 0.744 & 0.0048 & - & - & 1 & 0.0101 & 0.5535 & 0.0007 \\
$\quad$ Ants & 1 & 0.0924 & 1 & 0.0101 & - & - & 0.6354 & 0.068 \\
Plants & -0.08642 & 0.5548 & 0.5535 & 0.0007 & 0.6354 & 0.068 & - & - \\
\hline
\end{tabular}

